Automotive and

VDI Traffic Systems Technology

VDI-Berichte 2357

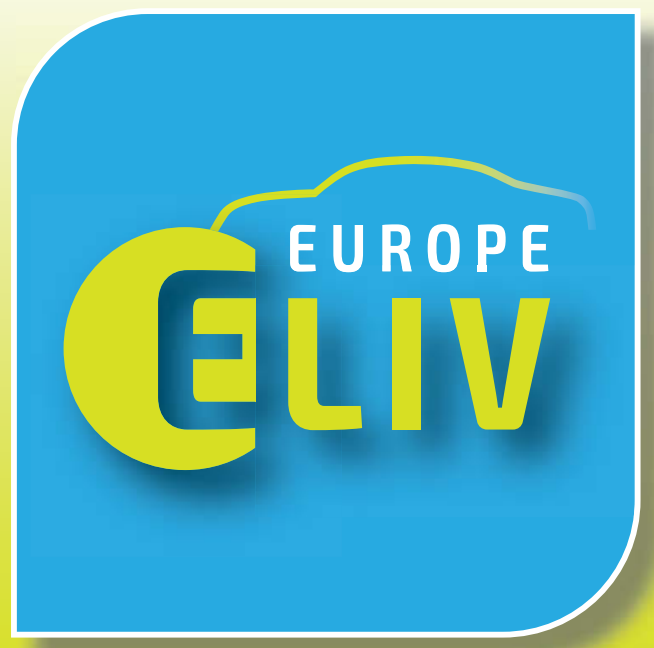

$19^{\text {th }}$ International Congress

\title{
ELIV 2019
}

October 16-17, 2019, Bonn 
https://doi.org/10.51202/9783181023570-1

Generiert durch IP '172.22.53.54', am 26.04.2023, 16:47:34.

Das Erstellen und Weitergeben von Kopien dieses PDFs ist nicht zulässig. 


\section{VDI-BERICHTE}

Herausgeber:

VDI Wissensforum GmbH 
Bibliographische Information der Deutschen Nationalbibliothek

Die Deutsche Nationalbibliothek verzeichnet diese Publikation in der Deutschen Nationalbibliographie;

detaillierte bibliographische Daten sind im Internet unter www.dnb.de abrufbar.

Bibliographic information published by the Deutsche Nationalbibliothek (German National Library)

The Deutsche Nationalbibliothek lists this publication in the Deutsche Nationalbibliographie (German National Bibliography); detailed bibliographic data is available via Internet at www.dnb.de.

\section{(c) VDI Verlag GmbH · Düsseldorf 2019}

Alle Rechte vorbehalten, auch das des Nachdruckes, der Wiedergabe (Photokopie, Mikrokopie), der Speicherung in Datenverarbeitungsanlagen und der Übersetzung, auszugsweise oder vollständig.

Der VDI-Bericht, der die Vorträge der Tagung enthält, erscheint als nichtredigierter Manuskriptdruck.

Die einzelnen Beiträge geben die auf persönlichen Erkenntnissen beruhenden Ansichten und Erfahrungen der jeweiligen Vortragenden bzw. Autoren wieder. Printed in Germany. 


\section{Content}

Foreword. . . . . . . . . . . . . . . . . . . . . . . . . .

\section{ADAS}

Seeing With Sound - Next-level 3D ultrasonic sensors based on echolocation. . . . . . . . . 5 N. Knappstein, Toposens, Munich

Ensuring the reliability, availability and safety of fully automated and autonomous transport systems through modern system architectures $\ldots \ldots \ldots \ldots \ldots \ldots \ldots$ J. Heinrich, A. Braasch, Institut für Qualitäts- und Zuverlässigkeitsmanagement GmbH, Wuppertal;

F. Plinke, Institut für Q Qualitäts- und Zuverlässigkeitsmanagement GmbH, Hamburg

ADAS/AD Systems: Efficient Testing \& Validation - From data acquisition to data analytics . . . 21 M. Kremer, M. Kreutz, M. Luxen, S. Christiaens, FEV Europe GmbH, Aachen

Problems and solution spaces for driver-initiated handover from automatic to manual

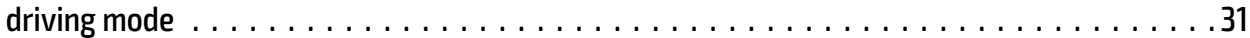
J. Klesing, Nexteer Automotive, Auburn Hills, USA;

5. Safour, Nexteer Automotive, Paris, France

\section{UX}

User-centred development of a display concept for fully automated driving A methodical approach.

L. Gauer, I. Totzke, Audi Electronics Venture GimbH, Gaimersheim

UX in the Automotive Industry - How to make it comparable? . . . . . . . . . . . . . . . 57

R. Ludwig, P3 automotive GmbH, Stuttgart

Development of the Cockpit-UI/UX of the Taycan in an Agile Way - Less is More

L. Krauß, E. Kögler, M. Bayer, S. Wiechmann, M. Worch, M. Mohamad,

Dr. Ing. h. c. F. Porsche AG, Weissach

3D-Displays with Lightfield Technology for a natural look and feel - User experience

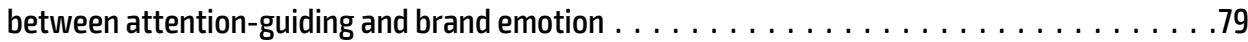
K. Hohmann, F. Rabe, C. Menzenbach, Continental Automotive GmbH, Babenhausen 


\section{$>$ E-Vehicles}

Future e-mobility and the change in system requirements - The interplay between battery and thermal management for different mobility concepts .

L. Schindele, D. Schütz, F. Heber, P. Sailer, G. Le Hen, N. Müller, Robert Bosch GmbH, Stuttgart

Modeling and identification of electrochemical energy storage for drive train development Review and evaluation . . . . . . . . . . . . . . . . . . . . . . . . . . . . . . . . . . . 101

P. Gesner, F. Kirschbaum, F. Landenberger, J. Scheiffele, Daimler AG, Stuttgart;

L. Morawietz, B. Bäker, Technische Universität Dresden, Institut für Automobiltechnik (IAD), Dresden

Condition monitoring for failure monitoring of power electronic assemblies . . . . . . . . 115 5. Wagner, F. Wüst, S. Trampert, F. Sehr, A. Middendorf, O. Wittler, Fraunhofer Institut für Zuverlässigkeit und Mikrointegration (IZM), Berlin;

M. Schneider-Ramelow, Technische Universität Berlin

Holistic Energy Management of 48V Mild Hybrid Vehicles . . . . . . . . . . . . . . . . . 127

P. Griefnow, J. Andert, M. Engels, RWTH Aachen University, Aachen;

J. Richenhagen, D. Jolovic, FEV Europe GmbH, Aachen

Easy Integration of 48V Mild Hybridization by Dual Voltage Battery Management Realizing $\mathrm{CO}_{2}$ saving potentials by low implementation efforts. . . . . . . . . . . . . . . 139 B. Fähnrich, A. Körner, HELLA GmbH \& Co. KGaA, Lippstadt

48 Volt High Power: Electric Drive for Excellent CO Emissions \& Electric Driving Features . . . 153 F. Graf, S. Baensch, T. Knorr, D. Ellmer, C. Marechal, Division Powertrain, Continental Automotive GmbH, Regensburg, Continental France SAS, Toulouse, France

Efficiency Advantages of SiC in Electric Drive Train Applications . . . . . . . . . . . . . . . . . . 169 T. Grasshoff, 0. Tamm, SEMIKRON International GmbH, Nürnberg

The Transition of EV Applications from Silicon to Silicon Carbide - Helping the power electronics design community overcome reliability challenges for EV applications that use silicon carbide . . . . . . . . . . . . . . . . . . . . . . . . . . . . . . 177 A. Kashyap, A. Gendron-Hansen, D. Sdrulla, B. Odekirk, Microchip Technology Inc., Bend, Oregon, USA

Modular DC-DC converter for high-performance fuel-cell systems in trucks and buses . . . . 189 T. Bürger, Kunal Goray, AVL SFR, Regensburg;

F. Berg, W. Resende, AVL List GmbH, Graz, Austria 


\section{$>$ End-2-End}

Future electric/electronic architecture - Sustainable design of a digital in-vehicle backend

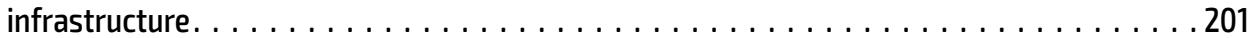
M. Traub, H.-U. Michel, BMW Group, München

Function- and Service-Orientation - a Game Changer for the E/E-Architecture of Tomorrow. . 213 R. Roppel, M. Görber, Dr. Ing. h.c. F. Porsche AG, Weissach

Vehicular RF Architectures - Managing integration of next generation automotive wireless systems. . . . . . . . . . . . . . . . . . . . . . . . . . . . . . . . . . . . . 227

T. Zipper, Continental Automotive GmbH, Regensburg;

R. Gee, Continental Automotive Japan KK, Yokohama, Japan

Going from an Electronic Unit Centric Development to Application Software Centric Requires a Different Architecture Mindset in Automotive. . . . . . . . . . . . . . . . . . 239 A. Magnuson, Volvo Group Truck Technology, Gothenburg, Sweden

Using Cloud-Based Electronic Horizons to Enable Distributed Driving Functions . . . . . . . . 255 P. Engel, A. Geraldy, J. Wolter, Robert Bosch GmbH, Hildesheim

Use of open source software in automotive safety projects - A decision tree for the usage of open source software components in safety projects . . . . . . . . . . . . . 269 R. Grave, Elektrobit Automotive GmbH, Erlangen

\section{Mission D}

Trucks as the drivers of connectivity-based innovation - What the passenger car sector can learn from the experience already gained in trucks today . . . . . . . . . . . . . . . 275 G. Mabire, Continental Automotive GmbH, Frankfurt am Main

Functions on demand - Enabler for digital business with car functions - Challenges of

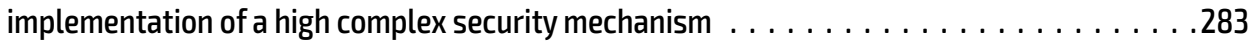
J.-K. Landgraf, A. Fabri, AUDI AG, Ingolstadt

System of systems structured data for mobility services. . . . . . . . . . . . . . 293

Y. Chazal, Renault, Paris, France;

A. M. Hein, Laboratoire Genie Industriel, CentraleSupélec, Université Paris-Saclay,

Paris, France;

5. Boutin, Knowledge Inside, Versailles, France 


\section{Data Management}

Building a Standardized Data Pipeline from the Cloud to All In-Vehicle ECUs and Sensors A New Opportunity for the Connected Car. . . . . . . . . . . . . . . . . . . . . . 307 5. Acharya, Excelfore, Fremont, California, USA;

M. Gardner, Molex, Lisle, Illinois, USA;

5. Herz, Hella GmbH, Lippstadt;

C. Hosner, Alpine Electronics, Auburn Hills, Michigan, USA;

F. Lesbroussart, ZF Friedrichshafen AG, Friedrichshafen

Data Structures and Interfaces for High-resolution Maps in Rapid Prototyping Applications of Highly Automated Driving . . . . . . . . . . . . . . . . . . . . 319 M. Giertzsch, Opel Automobile GmbH, Rüsselsheim

Multilateralism at its best: A blockchain-based platform enabling data sharing, monetization and service differentiation in the automotive industry . . . . . . . . 333 K. Bader, V. Knaup, S. Schneider, Continental Secure Data Germany GmbH, Aschheim

\section{$\rightarrow$ Mission D}

Al and the Evolution of Model-Based Design . . . . . . . . . . . . . . . . . . . 347

J. Tung, MathWorks, Natick, Massachusetts, USA

On modern automotive software development - Forever stuck in the middle? . . . . . . . . 353

R. Schmidt-Clausen, U. Reder, R. Lange, e.solutions GmbH, Ingolstadt

The Future of Digital Car Access - Service Potentials and Ecosystem Challenges . . . . . . . . 359

K. L. Barbehön, O. Müller, D. Knobloch, BMW AG, München

\section{$\rightarrow$ ADAS KI}

Potential of Training Neural Networks Using Virtual Environments

R. Pfeffer, N. Ahn, IPG Automotive GmbH, Karlsruhe

Mission Al in Automotive - Collaboration Models and Functional Safety. . . . . . . . . . . . 375

U. Bodenhausen, Vector Consulting Services GmbH,

U. Bodenhausen Al Coaching, Stuttgart 


\section{ADAS}

Engineering and Hardening of Functional Fail-Operational Architectures for Highly Automated Driving - Identifying and shaping the operational design domain

R. Adler, D. Schneider, Fraunhofer IESE, Kaiserslautern;

T. Fukuda, Hitachi Automotive System Europe GmbH

Safety for Automated Driving with High Performance ECUs . . . . . . . . . . . . . . . . . . 395

M. Oertel, J. Wolf, Vector Informatik GmbH, Stuttgart

Impact of Cybersecurity and Safety Standards on ADAS Software Development Practices . . .407 0. Ur-Rehman, G. Wallraf, B. Holderbaum, M. Jentges, FEV Europe GmbH, Aachen

\section{Security}

Are you Security Compliant? - Current Automotive Security Legislations, Potential Impacts to Automotive OEMs \& Suppliers, and First Action Proposals . . . . . . . . . . . . . . . . . 419 M. Minzlaff, Marko Wolf, ESCRYPT GmbH, Munich

Integration of Cybersecurity into Development Processes - A Case Study . . . . . . . . . . 423

F. Stahl, AVL Software and Functions GmbH, Regensburg

The transition to HPC-based vehicle architectures - Cyber Security Implications . . . . . . . . 431

A. Shomer, Argus Cyber Security, Tel-Aviv, Israel

Enhancing In-Vehicle Communication by Authentication and Security - An incremental approach with an example for CAN message authentication . . . . . . . . . . . . . 443 A. Hahn, Automotive Security Group, Microchip Technology Munich GmbH, Heilbronn

Hardware matters: how one chip can impact the security of a connected vehicle . . . . . . . 455 M. Brunner, H. Adlkofer, Infineon Technologies AG, Neubiberg

Embedded Intrusion Detection based on AI - A Data-Driven Approach . . . . . . . . . . . .469 A. Weichslgartner, Audi Electronics Venture GmbH, Gaimersheim

Continuous Security Testing for the Automotive Domain . . . . . . . . . . . . . . . . . . . . 479

S. Greiner, H. Löhr, P. Duplys, Robert Bosch GmbH, Renningen 


\section{$>$ Architectures + Software}

AUTOSAR Adaptive Platform - A standardized SW platform for intelligent vehicles with functional safety and data integrity .

G. Reichart, M. Niklas, AUTOSAR partnership, Aschheim near Munich

Service-Oriented HPC Communication Standard for Vehicle Lifecycle Management . . . . . . .503 A. Schleicher, DSA Daten- und Systemtechnik GmbH, Aachen

How to Improve Automotive Testing in an Agile Development Process - A Review of Popular Testing Methods and Overview of Advanced Automated User Interface Testing . . . . . . . . . 519 D. Robinson, Altia Europe GmbH, Nuremberg

\section{$>$ Mission D - Charging}

800V Fast Charging is Reality - From the Vision in 2015 to Reality in 2019 . . . . . . . . . . 529 0 . Bitsche, Dr. Ing. h.c. F. Porsche AG, Weissach

\section{On-Board 2.0}

Addressing the challenges in designing fail-operational architectures for autonomous driving platforms - Tailoring fail-operational systems based on production experience in the aerospace industry for the automotive use cases . . . . . . . . . . . . . 537 5. Poledna, TTTech Auto AG, Vienna, Austria

Boost Safety \& Styling for vehicle lighting - Individualization and new Functionalities . . . . 551 M. Kleinkes, W. Pohlmann, C. Wilks, HELLA GmbH \& Co. KGaA, Lippstadt

CAN FD Light - A novel communication bus supporting digitalization and customization

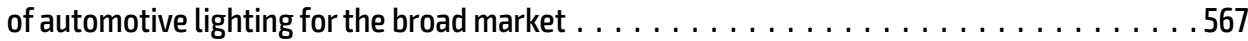

F. Rennig, J. Barthel, M. Sanza, D. Tagliavia, STMicroelectronics Application GmbH, Aschheim-Dornach near Munich

Digital Light - Function \& Design on Demand utilized for Car2X Communication. . . . . . . . . 581 M. Kruppa, W. Thomas, AUDI AG, Ingolstadt 